\title{
Regiocontrol in the Nickel-Catalyzed Aldehyde-Alkyne Reductive Coupling
}

Metal-Catalyzed Asymmetric Synthesis and Stereoselective

Reactions

\section{Key words}

propargylation

regioselective hydrometalation

nickel

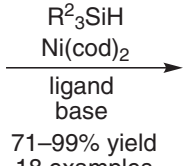<smiles>[2H]C([10BH2])/C([17OH])=C\P</smiles><smiles>[B]C(=CP)C(C)OCC</smiles>

favored for ligand $\mathbf{A}$ or $\mathbf{B}$

favored for ligand $\mathbf{C}$ or $\mathbf{D}$

Ligands:<smiles>[3H]C1C(N(CCC)C(C)C)=C1N(C(C)C)C(C)C</smiles>

A<smiles>Cc1cc(C)c(-n2cc[n+](-c3c(C)cc(C)cc3C)c2)c(C)c1</smiles>

B<smiles>CCCc1cccc(C(C)C)c1N1C=[N+](c2c(C(C)C)cccc2C(C)C)C(P)C1PCC</smiles>

C R $=\mathrm{H}$
D $\mathrm{R}=\mathrm{Ph}$

Selected examples:<smiles>CC#CPCC</smiles><smiles>CC(C)(C)[18OH]</smiles>

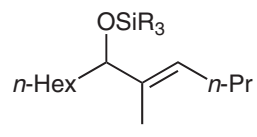<smiles>C/C=C(\CCC)C(OCC)OCCC</smiles>

ligand A: regioselectivity $=88: 12$

ligand C: regioselectivity $=7: 93$ $85 \%$ yield<smiles>O=CO</smiles><smiles>CC#CC1=CCC2CC1C2</smiles><smiles>CC(C)[18OH]</smiles><smiles>CCCCCC(C)OC(C)CC</smiles><smiles>CC=CC(OCC)C(OCC)OCCC</smiles>

ligand $\mathbf{B}$ : regioselectivity $=97: 3$

$$
99 \% \text { yield }
$$

ligand $\mathbf{D}$ : regioselectivity = 9:91 $77 \%$ yield

Significance: The reductive coupling of alkynes with aldehydes is a common method for preparing allylic alcohols. When unsymmetrical alkynes are used two regioisomeric products can be formed. Regiocontrol is possible with a strong steric or electronic bias in the alkyne. The authors have developed catalyst systems which are exceptionally sensitive to steric differences in unsymmetrical alkynes, allowing either regioisomeric trisubstituted alkene to be synthesized.
Comment: Through careful choice of ligand and reducing agent, either regioisomer can be accessed in good yields with groups as similar as methyl and $n$-propyl on the alkyne. The inherent bias of, for example, conjugated alkynes can also be overcome to provide reductive coupling products that were previously inaccessible through similar methods. The optimal choice of reducing agent, base, and ligand is substrate-dependent; however, simple and straightforward guidelines are provided to make this a practical and useful method. 